\section{Phenyl Isothiocyanate Performance on Purple Nutsedge under Virtually Impermeable Film Mulch}

\author{
Sanjeev K. Bangarwa ${ }^{1,3}$, Jason K. Norsworthy ${ }^{1}$, Edward E. Gbur², \\ and John D. Mattice ${ }^{1}$
}

AdDitional INDEX wORDs. Cyperus rotundus, methyl bromide alternative, polyethylene mulch, soil fumigation, weed management

Summary. Purple nutsedge (Cyperus rotundus) is a troublesome weed in vegetable crops in the southern United States. Methyl bromide is widely used for effective purple nutsedge control in polyethylene-mulched vegetable crops. With the impending ban on methyl bromide in the United States, an effective alternative is needed. Laboratory and greenhouse experiments were conducted to determine the effect of phenyl isothiocyanate (ITC) concentration and exposure period on purple nutsedge tuber viability and to compare the retention of phenyl ITC in soil under low-density polyethylene (LDPE) and virtually impermeable film (VIF) mulches. Additionally, field experiments were conducted to evaluate the effectiveness of phenyl ITC under VIF mulch against purple nutsedge. A phenyl ITC concentration of $676 \mathrm{ppm}$ in soil for 3 days in a sealed environment reduced purple nutsedge tuber viability by $97 \%$ compared with a nontreated control. Phenyl ITC retention was higher in soil covered with VIF mulch than with LDPE mulch. The predicted half-life of phenyl ITC under LDPE and VIF mulch was 6.1 and 8.9 days, respectively. In field experiments, phenyl ITC at $1500 \mathrm{~kg} \cdot \mathrm{ha}^{-1}$ under VIF mulch suppressed purple nutsedge shoots and reduced viable tuber density $\geq 72 \%$, but control was not as effective as methyl bromide at $390 \mathrm{~kg} \cdot \mathrm{ha}^{-1}$ (67\% methyl bromide:33\% chloropicrin). Therefore, phenyl ITC up to $1500 \mathrm{~kg} \cdot \mathrm{ha}^{-1}$ under a VIF mulch is not a viable alternative to methyl bromide for effective purple nutsedge control.

$\mathrm{P}$ urple nutsedge is the most problematic weed in vegetable crops in the southern United States (Webster, 2002). The success of purple nutsedge is associated with its perennial nature, prolific tuber and rhizome production, $\mathrm{C}_{4}$ carbon-fixation pathway, and release of allelopathic compounds (Anderson, 1999; Stoller and Sweet, 1987). All the above characteristics together make purple nutsedge a highly competitive and difficult-tocontrol weed in vegetable crops. Season-long interference with purple nutsedge has reduced the yield of cucumber (Cucumus satious) by $43 \%$; tomato (Solanum lycopersicum) by $44 \%$, lettuce (Lactuca sativa) by $54 \%$, cilantro (Coriandrum sativum) by

We gratefully acknowledge the technical support provided by Michael Grubbs, Michael Wilson, Keith Warnock, Griff Griffith, Joshua Still, Mayank Malik, Prashant Jha, Marcos Oliveira, and Rex Blanton, and editorial support provided by Ms. Marilyn McClelland.

${ }^{1}$ Department of Crop, Soil, and Environmental Sciences, University of Arkansas, 1366 West Altheimer Drive, Fayetteville, AR 72704

${ }^{2}$ Agricultural Statistics Laboratory, University of Arkansas, 101 Agricultural Annex Building, Fayetteville, AR 72701

${ }^{3}$ Corresponding author. E-mail: sbangarw@uark.edu.
61\%, bell pepper (Capsicum annuum) by $73 \%$, and radish (Raphanus satious) by 100\% (Morales-Payan et al., 1996, 1997a, 1997b, 1998; Santos et al., 1998; William and Warren, 1975).

Methyl bromide, a preplant soil fumigant, is widely used in the southern United States for weed control in polyethylene-mulched vegetable production (Duniway, 2002). However, methyl bromide is considered to be a contributor to ozone depletion, and therefore will be banned in the United States in the near future (U.S. Environmental Protection Agency, 2008).
Weed control will be challenging in polyethylene-mulched vegetables in the absence of methyl bromide, especially for purple nutsedge, which can easily penetrate polyethylene mulch (Patterson, 1998). Thus, there is an urgent need to develop an effective alternative to methyl bromide.

Isothiocyanates (ITC) are a family of compounds composed of nitrogen $(\mathrm{N})$, carbon $(\mathrm{C})$, and sulfur $(\mathrm{S})$, with an alkyl or aryl side chain (R) having the basic structure of $\mathrm{R}-\mathrm{N}=\mathrm{C}=\mathrm{S}$. ITC have shown herbicidal activity on several weed species, including purple nutsedge (Norsworthy and Meehan, 2005a, 2005b; Norsworthy et al., 2006; Peterson et al., 2001). Although the mode of action of ITC is still unknown, they are believed to interact with enzymes related to germination to prevent weed seed germination, including purple nutsedge tubers (Drobinca et al., 1977; Peterson et al., 2001; Norsworthy et al., 2006). Additionally, Norsworthy et al. (2006) showed the negative impact of various ITC on shoot density and shoot biomass production of purple nutsedge.

Isothiocyanates are highly volatile compounds, and $>90 \%$ of ITC are lost primarily through volatilization (Brown and Morra, 1995). Hence, ITC are vulnerable to rapid loss in an open environment similar to field conditions, thereby linking weed control efficacy with the ability to reduce volatile losses. Volatilization losses of ITC can be partially overcome by using lowpermeability polyethylene mulches, which aid ITC retention and enhance herbicidal efficacy (Norsworthy et al., 2006). In earlier experiments, virtually impermeable film (VIF) mulch retained higher concentrations of fumigants (methyl bromide and 1,3-dichloropropene + chloropicrin) compared with conventionally used low-density

\begin{tabular}{llll}
\hline $\begin{array}{l}\text { Units } \\
\text { To convert U.S. to SI, } \\
\text { multiply by }\end{array}$ & U.S. unit & SI unit & $\begin{array}{l}\text { To convert SI to U.S., } \\
\text { multiply by }\end{array}$ \\
\hline 29.5735 & $\mathrm{fl} \mathrm{oz}$ & $\mathrm{mL}$ & 0.0338 \\
0.3048 & $\mathrm{ft}$ & $\mathrm{m}$ & 3.2808 \\
0.0929 & $\mathrm{ft}^{2}$ & $\mathrm{~m}^{2}$ & 10.7639 \\
2.54 & inch $(\mathrm{es})$ & $\mathrm{cm}$ & 0.3937 \\
0.4536 & $\mathrm{lb}$ & $\mathrm{kg}$ & 2.2046 \\
1.1209 & $\mathrm{lb} / \mathrm{acre}$ & $\mathrm{kg} \cdot \mathrm{ha}^{-1}$ & 0.8922 \\
0.0254 & $\mathrm{mil}$ & $\mathrm{mm}$ & 39.3701 \\
28.3495 & $\mathrm{oz}$ & $\mathrm{g}$ & 0.0353 \\
1 & $\mathrm{ppm}$ & $\mu \mathrm{g} \cdot \mathrm{g}^{-1}$ & 1 \\
6.8948 & $\mathrm{psi}$ & $\mathrm{kPa}$ & 0.1450 \\
$\left({ }^{\circ} \mathrm{F}-32\right) \div 1.8$ & ${ }^{\circ} \mathrm{F}$ & ${ }^{\circ} \mathrm{C}$ & $\left(1.8 \times{ }^{\circ} \mathrm{C}\right)+32$
\end{tabular}


polyethylene mulch (LDPE) (Santos et al., 2007; Yates et al., 2002). Although ITC are comparatively less volatile than the above-mentioned fumigants, VIF reduces the loss of methyl ITC by $40 \%$ compared with LDPE mulch under laboratory experiments (Austerweil et al., 2006). Therefore, VIF mulch is expected to reduce the rate of loss of ITC under field conditions, in turn improving weed control.

Phenyl ITC was evaluated in the present study because of the lack of available data on phenyl ITC efficacy against purple nutsedge. In a previous greenhouse experiment, phenyl ITC at a concentration of $1352 \mathrm{ppm}(\mathrm{w} /$ w) in dry soil reduced yellow nutsedge emergence by $>90 \%$ (Norsworthy and Meehan, 2005b). Because of the morphological similarities between yellow nutsedge and purple nutsedge, it was hypothesized that phenyl ITC would provide effective purple nutsedge control, and its efficacy would be enhanced by increasing the phenyl ITC concentration and by using VIF mulch. The objectives of this research were to determine the lethal concentration and exposure period of phenyl ITC needed for purple nutsedge tuber mortality, to compare the retention of phenyl ITC in soil under LDPE and VIF mulches, and to determine the efficacy of phenyl ITC under VIF mulch against purple nutsedge under field conditions.

\section{Materials and methods}

LOCATION AND SOIL TYPE. Laboratory and greenhouse experiments were conducted twice at Fayetteville, $A R$, in 2007. The soil type used for these experiments was a Razort silt loam (fine-loamy, mixed, active, nonacid, mesic Millic Hapludalfs) with $1.7 \%$ organic matter and a $\mathrm{pH}$ of 6.1 . Field experiments were conducted in 2006 at Clemson, SC, and in 2007 at Fayetteville, AR. The soil type at Clemson was a Congaree silt loam (fine-loamy, mixed, active, non-acid, thermic Oxyaquic Udifluvents) with $1.5 \%$ organic matter and a $\mathrm{pH}$ of 6.1 . The soil type at Fayetteville was classified as a Razort silt loam (fine-loamy, mixed, active, non-acid, mesic Millic Hapludalfs) with $1.7 \%$ organic matter and a $\mathrm{pH}$ of 6.1.

Greenhouse experiment. Purple nutsedge tuber viability was evaluated after a specific exposure period to two concentrations of phenyl ITC (97\% purity; Alfa Aesar, Ward Hill, MA). For this purpose, $1 \mathrm{~kg}$ of autoclave-sterilized soil was treated with phenyl ITC (molecular weight $=135$ g) to produce a concentration of 68 and $676 \mathrm{ppm}(\mathrm{w} / \mathrm{w})$ in dry soil, which correspond to field rates of 75 and $750 \mathrm{~kg} \cdot \mathrm{ha}^{-1}$, respectively. Phenyl ITC was mixed with $100 \mathrm{~mL}$ of distilled water for uniform distribution of phenyl ITC in soil. Because phenyl ITC is less polar than water, phenyl ITC was vigorously mixed in water by continuous agitation to create a uniform suspension of ITC in water. This suspension was then intermittently poured into plastic bags containing soil and was thoroughly mixed for uniform treatment of soil. Twenty purple nutsedge tubers were mixed in the treated $1 \mathrm{~kg}$ of soil, and the soil was immediately transferred to 32 -fl oz glass jars, and the jars were sealed with a Teflon cap. The jars were placed in a greenhouse for a period of $0,1,3,7,14$, or $21 \mathrm{~d}$. Greenhouse conditions were $30 / 22^{\circ} \mathrm{C}$ day/night temperatures and $14 / 10-\mathrm{h}$ day/ night light periods. The 0 - $\mathrm{d}$ period was considered as a control treatment in which tubers were not treated with phenyl ITC. Each run was a randomized complete block design with three blocks (replications) and two concentrations and six time periods. A separate set of jars was maintained for each exposure period. Following each period, tubers were removed from the jars, washed, and tested for sprouting in pots filled with sterilized soil for 4 weeks in the greenhouse under the same conditions described above. Sprouted tubers were counted and removed from the pots periodically. After 4 weeks, the non-sprouted tubers were removed from the pots and washed with distilled water. Nonsprouted tubers were tested for viability based on firmness and pulp color. Tubers that were rotten and tubers that were firm but completely lacked white pulp inside were considered nonviable. The sprouted and viable tuber counts were added and collectively considered as viable tubers. Because no tubers were viable for either treatment in either of the runs after day 7 , only data from exposure periods 1,3 , and $7 \mathrm{~d}$ were included in the analysis. Data from day 0 were excluded from analysis because it was a control treatment with no phenyl ITC. Runs and blocks (replications) were random effects and phenyl ITC concentration was a fixed effect. Exposure period was treated as a fixed effect rather than as a continuous covariate because there were only three days $(1,3$, and $7 \mathrm{~d})$ in which viable tubers were recovered. Therefore, concentration and exposure period had a $2 \times 3$ factorial treatment structure. Viable tubers (percentage control) were subjected to analysis of variance using $\mathrm{SAS}^{\circledR}$ (version 9.2; SAS Institute Inc., Cary, NC). Viable tuber means under two phenyl ITC concentrations were compared at each day with single df contrasts at $\alpha=0.05$.

LABORATORY EXPERIMENT. TO determine the retention of phenyl ITC in soil covered with LDPE and VIF mulches, phenyl ITC in $100 \mathrm{~mL}$ of water was added to $1 \mathrm{~kg}$ of autoclave-sterilized soil to create a phenyl ITC concentration of $676 \mathrm{ppm}$ (w/ $\mathrm{w}$ ) in dry soil (equivalent to a field rate of $\left.750 \mathrm{~kg} \cdot \mathrm{ha}^{-1}\right)$. Treated $1 \mathrm{~kg}$ of soil was immediately transferred to 32 -fl oz glass jars, and the mouths of the jars were covered with a black LDPE mulch (1.0 mil thick; Robert Marvel Plastic Mulch, Annville, PA) or a black/white VIF mulch (1.3 mil thick; Polygro, Tampa, FL). The jars were placed in a greenhouse for $1,3,7$, 14 , or $21 \mathrm{~d}$ after treating the soil. Controlled conditions in the greenhouse were the same as those discussed above. A control treatment (day 0 ) was also established in which phenyl ITC was extracted immediately after treating the soil. A separate set of jars was maintained for each duration to facilitate destructive sampling. Each run was a randomized complete block design with three blocks (replications) and two mulches and six time periods. After each duration, phenyl ITC was extracted from the soil in jars using a standard procedure reported by Gardiner et al. (1999). Phenyl ITC was identified and quantified using a gas chromatograph (CP-3800; Varian, Palo Alto, $\mathrm{CA}$ ) attached to a mass spectrometer (Saturn-2200, Varian) using external standards. Data from the control treatment (day 0) were not included in statistical analysis. Runs and blocks were random effects and mulch was a fixed effect. The natural logarithm of the phenyl ITC concentration (percentage control) quantified from 
treated soil was regressed against time (days) using analysis of covariance techniques to allow the intercept and slope to differ by mulch using SAS ${ }^{\circledR}$ (version 9.2). Fitted lines were used to calculate the half-life of phenyl ITC under LDPE or VIF mulch. Approximate standard errors for half-lives were obtained using the delta method (Stuart and Ord, 1994).

FIELD EXPERIMENT. The test sites at both locations were naturally infested with purple nutsedge. The average purple nutsedge density at both sites ranged from 75 to 86 shoots $/ \mathrm{m}^{2}$ at initiation of the experiment. Before treatment application, the test sites were rototilled twice to destroy winter vegetation and loosen the soil for ease in forming raised beds and laying polyethylene mulch. In each year, the experiment was a randomized complete block design with three blocks (replications) and seven treatments. The treatments included six rates of phenyl ITC: $0,15,75,150,750$, and $1500 \mathrm{~kg} \cdot \mathrm{ha}^{-1}$ (equivalent to phenyl ITC concentrations of $0,14,68,135$, 676, and $1352 \mathrm{ppm}(\mathrm{w} / \mathrm{w})$ in soil) applied under VIF mulch (1.3 mil thick; Polygro). Additionally, a standard treatment of $390 \mathrm{~kg} \cdot \mathrm{ha}^{-1}$ methyl bromide + chloropicrin $(67: 33, \mathrm{v} / \mathrm{v})$ under VIF mulch was included for comparison in each block. Phenyl ITC was applied on the soil in 30-ft-long and 5-ft-wide plots using a carbon dioxidepressurized backpack sprayer (R\&D Sprayers, Opelousas, LA) calibrated to deliver $30 \mathrm{gal} /$ acre of spray solution at 40 psi pressure, using acetone (Klean Strip; Win Barr, Memphis, TN) as a carrier. Acetone was used as carrier because phenyl ITC (nonpolar) is more soluble in acetone (nonpolar) than water (highly polar), which was used in greenhouse and laboratory studies. This is because continuous agitation is not possible under field conditions to create a uniform suspension of phenyl ITC in water. Repeated passes were made over plots receiving the two higher rates $\left(750\right.$ and $1500 \mathrm{~kg} \cdot \mathrm{ha}^{-1}$ ).

Before field studies, greenhouse bioassays were conducted to test any impact of acetone concentration (equivalent to the maximum field rate) under LDPE or VIF mulch on purple nutsedge tuber sprouting. The experiment showed that purple nutsedge sprouting was unaffected by acetone concentrations used in the field experiment (data not shown).
Immediately after application to soil, phenyl ITC was incorporated into the top 3 inches of soil using a rototiller. Six-inch-tall raised beds were prepared at 6 - $\mathrm{ft}$ centers after phenyl ITC incorporation, and beds were covered with black/white VIF mulch using a tractor-mounted plastic layer. Simultaneously, a drip tape was placed under the VIF mulch in the center of beds for irrigation. Immediately after laying the mulch, adjacent beds were separated from each other by cutting the polyethylene mulch and covering the edges with soil to prevent volatile phenyl ITC movement across treatments. Each experimental unit contained a raised bed $30 \mathrm{ft}$ long and $2.3 \mathrm{ft}$ wide at the top. Weeds growing in the bare-ground area between parallel beds were controlled by application of paraquat (Gramoxone Inteon $2 \mathrm{EC}$; Syngenta Crop Protection, Greensboro, NC) using a hooded sprayer.

Data were recorded on purple nutsedge shoot and tuber density from central 15 -ft-long by 2.3 -ft-wide area on a raised bed. Purple nutsedge shoots that penetrated through the VIF mulch were counted at 2 and 4 weeks after treatment application. Additionally, shoot density was recorded on bare-ground (non-mulched) soil from two random $1-\mathrm{m}^{2}$ quadrants placed in a non-experimental area of the test site at 4 weeks. This was done to test any physical suppression of purple nutsedge provided by the VIF mulch alone in the absence of phenyl ITC. After 4 weeks, VIF mulch was removed, and live shoots were counted that were growing under the mulch. In addition, 10 soil core samples were randomly taken from the central $15-\mathrm{ft}$ length of each bed, and soil was washed to obtain purple nutsedge tubers. Viable tubers were quantified by the procedure presented above in the greenhouse experiment. Density of shoots and viable tubers recorded were converted into per square meter before analyzing. Years and blocks (replications) were treated as random effects. The natural logarithm of each response variable (shoot or tuber density) was regressed as a quadratic function of the natural logarithm of phenyl ITC rate +1 to characterize the purple nutsedge response in relation to increased phenyl ITC rate $\left(\mathrm{SAS}^{\circledR}\right.$, version 9.2). The fitted models were used to estimate the phenyl ITC rate equivalent at the observed mean response from the methyl bromide treatment.

\section{Results and discussion}

Greenhouse experiment. Tuber viability was affected by the phenyl concentration over time. All the tubers were viable (100\% viability) at day 0 (data not shown). Tuber viability declined at each phenyl ITC concentration starting from day 1 . Tuber viability was lower at the high phenyl ITC concentration (676 ppm) than at low concentration ( $68 \mathrm{ppm})$ at 1,3 , and $7 \mathrm{~d}$ (Fig. 1). Exposure to phenyl ITC at 676 ppm dry soil for $3 \mathrm{~d}$ in a sealed jar reduced the purple nutsedge tuber viability by $97 \%$ (Fig. 1). However, at the low concentration of phenyl ITC (68 ppm), $7 \mathrm{~d}$ were needed to reduce tuber viability by $79 \%$. Consequently, an exposure period of $7 \mathrm{~d}$ at $676 \mathrm{ppm}$ and an exposure period of $14 \mathrm{~d}$ at 68 ppm of phenyl ITC in a sealed jar was sufficient enough to cause complete mortality ( $0 \%$ viability) of purple nutsedge tubers (data not shown). This indicates that for effective nutsedge suppression, the exposure period should be extended when using a low phenyl ITC concentration, and vice versa. The above results are in agreement with Teasdale and Taylorson (1986), who suggested that ITC concentration and length of exposure to target weed species are critical for weed suppression. Similarly, Norsworthy and Meehan (2005b) found that for yellow nutsedge emergence to be reduced $92 \%$, a phenyl ITC concentration of $1352 \mathrm{ppm}$ in soil is required. However, the above-mentioned studies were conducted in open trays, thus, it is possible that a considerable amount of phenyl ITC was volatilized from the treated soil. In the present experiment, even a low phenyl ITC concentration of 68 ppm dry soil in a sealed environment was effective against purple nutsedge, indicating that low rates can be used for effective control of purple nutsedge if losses of phenyl ITC are minimized. Therefore, these results suggest that under field conditions, permeability of polyethylene mulches to phenyl ITC may play an important role in governing phenyl ITC efficacy against purple nutsedge, especially when applied at low rates.

LABORATORY EXPERIMENT. Recovery of phenyl ITC concentration in soil in the control treatment $(0 \mathrm{~d}$ 
after treating soil) was 39\% (data not shown), which was taken into account in quantifying phenyl ITC concentration in soil samples. The retention of phenyl ITC under LDPE and VIF mulches was characterized by a negative linear relationship $[\ln (y)=-a x+b]$, where $\mathrm{y}$ is the phenyl ITC concentration (\% of control) and $\mathrm{x}$ is the duration (days). Specific regression equations for LDPE and VIF mulches are $\ln (\mathrm{y})=-0.1138 \mathrm{x}+4.5254$ and $\ln (\mathrm{y})=-0.0781 \mathrm{x}+4.5822$, respectively (Fig. 2). Phenyl ITC dissipation

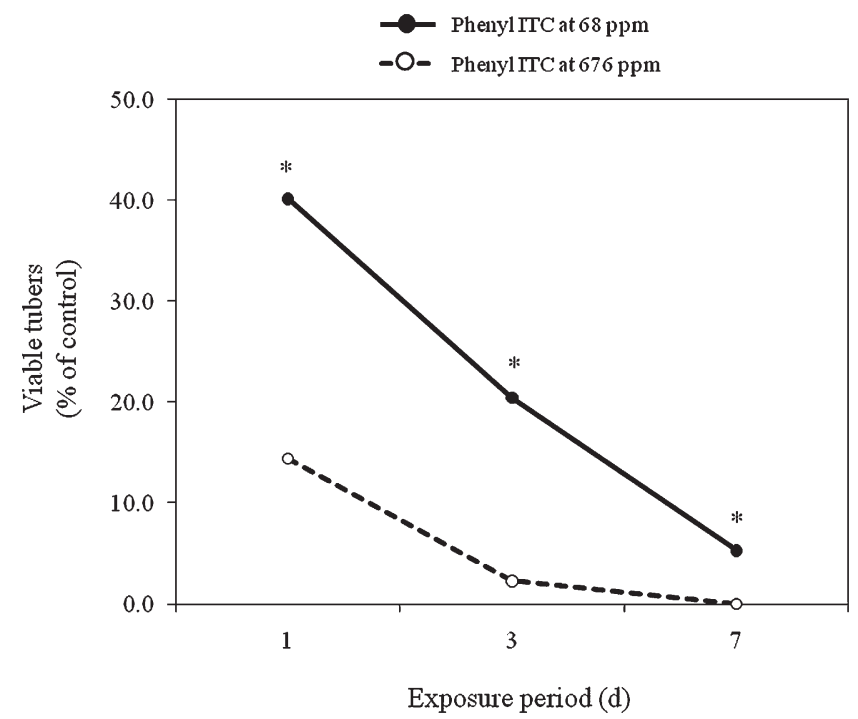

Fig. 1. Effect of phenyl isothiocyanate (ITC) concentration in a sealed environment on purple nutsedge tuber viability over time $(1,3$, and $7 \mathrm{~d})$, averaged over two experimental runs. Soil with purple nutsedge tubers was initially treated at day 0 with 68 and $676 \mathrm{ppm}(\mathrm{w} / \mathrm{w})$ of phenyl ITC. Tuber viability was 100\% at day 0 , and $0 \%$ at days 14 and 21 at each phenyl ITC concentration. Circles (open and closed) are the means of viable tubers (percentage of control). Viable tuber means at each day with an asterisk are significantly different based on single df contrasts at $\alpha=0.05$. SE of each mean $=2.18 ; 1 \mathrm{ppm}=1 \mu \mathrm{g} \cdot \mathrm{g}^{-1}$.

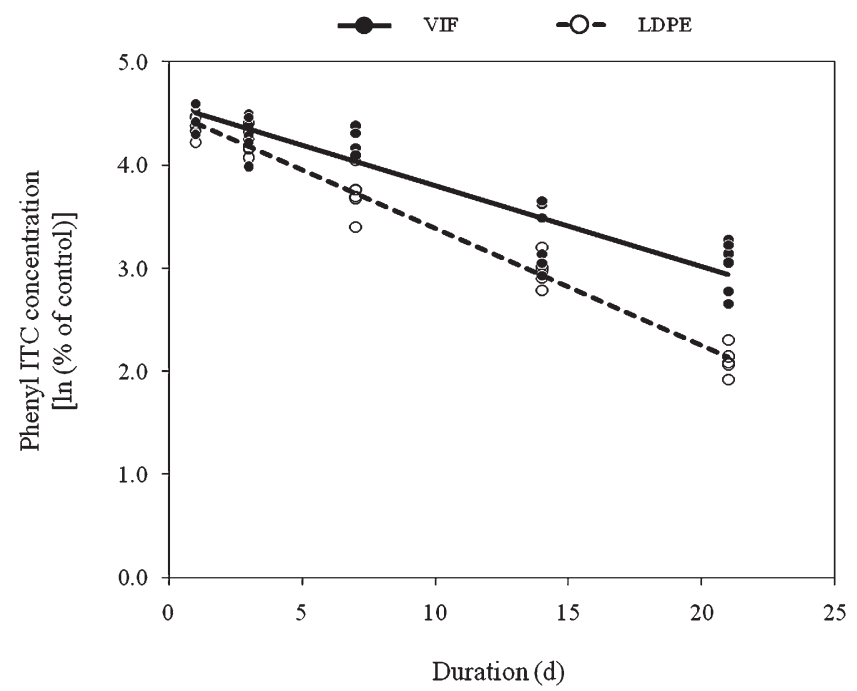

Fig. 2. Phenyl isothiocyanate (ITC) retention under low-density polyethylene (LDPE) and virtually impermeable film (VIF) mulches over time, averaged over two experimental runs. Soil was initially treated at day 0 with $676 \mathrm{ppm}(\mathrm{w} / \mathrm{w})$ of phenyl ITC. Circles (open and closed) are individual observations and lines (solid and dotted) are fitted regression equations. Regression equations are $\ln (y)=-0.1138 x+4.5254$ for LDPE mulch, and $\ln (y)=-0.0781 x+4.5822$ for VIF mulch, where $y$ is phenyl ITC concentration (percentage of control) and $x$ is duration (d); $1 \mathrm{ppm}=1 \mu \mathrm{g} \cdot \mathrm{g}^{-1}$.

increased with time under both types of polyethylene mulches, with $\geq 81 \%$ phenyl ITC loss from the treated soil at $21 \mathrm{~d}$ after treatment. However, regression analysis indicated that the intercept and slope were different for phenyl ITC retention response curves under LDPE and VIF mulch. Based on the equations, it is predicted that the half-life $\left(\mathrm{t}_{1 / 2}\right)$ of phenyl ITC was $6.09 \pm 0.27 \mathrm{~d}( \pm \mathrm{SE})$ under LDPE mulch and $8.88 \pm 0.54 \mathrm{~d}$ under VIF mulch. Similarly, in a previous laboratory experiment, loss of methyl ITC was reduced by $40 \%$ under a VIF mulch compared with LDPE mulch (Austerweil et al., 2006).

These results indicate a relatively higher retention capacity and slower dissipation rates of phenyl ITC from the treated soil covered with a VIF mulch compared with LDPE mulch. Higher retention of phenyl ITC under VIF mulch may be attributed to the polyamide barrier embedded in the polyethylene sheets of VIF mulch, which make it less permeable than LDPE mulch to volatile compounds (Yates et al., 2002). Additionally, the greater thickness of VIF mulch (1.3 mil) than LDPE mulch (1.0 mil) may have partially contributed to reduction of phenyl ITC losses from the soil. The less-permeable nature of VIF helps in maintaining a higher concentration of fumigants in the bedded soil for a longer time, thereby improving nutsedge control over LDPE (Santos et al., 2007). Therefore, purple nutsedge control from phenyl ITC may be improved by using VIF mulch over LDPE mulch.

Field experiment. Purple nutsedge shoot emergence through the plastic was influenced by phenyl ITC application rate, with a decline in shoot emergence with increasing phenyl ITC rates, and was explained by quadratic equations (Fig. 3, A and B). Specific equations were: $\ln (\mathrm{y})=-0.0325\{\ln (\mathrm{x}+$ l) $\}^{2}-0.0013\{\ln (\mathrm{x}+1)\}+1.4346$ at 2 weeks and $\ln (\mathrm{y})=-0.0222\{\ln (\mathrm{x}+1)\}^{2}$ $-0.0159\{\ln (\mathrm{x}+1)\}+1.7710$ at 4 weeks after treatment, where $y$ is the purple nutsedge shoot density (shoots per square meter) and $\mathrm{x}$ is the phenyl ITC rate (kilograms per hectare). Based on fitted model, purple nutsedge shoot density was predicted in nontreated plots, with 4.20 shoots $/ \mathrm{m}^{2}$ (back transformed values) after 2 weeks (Fig. 3A). Shoot density was decreased to 1.00 shoots $/ \mathrm{m}^{2}$ (76\% reduction) and 0.73 

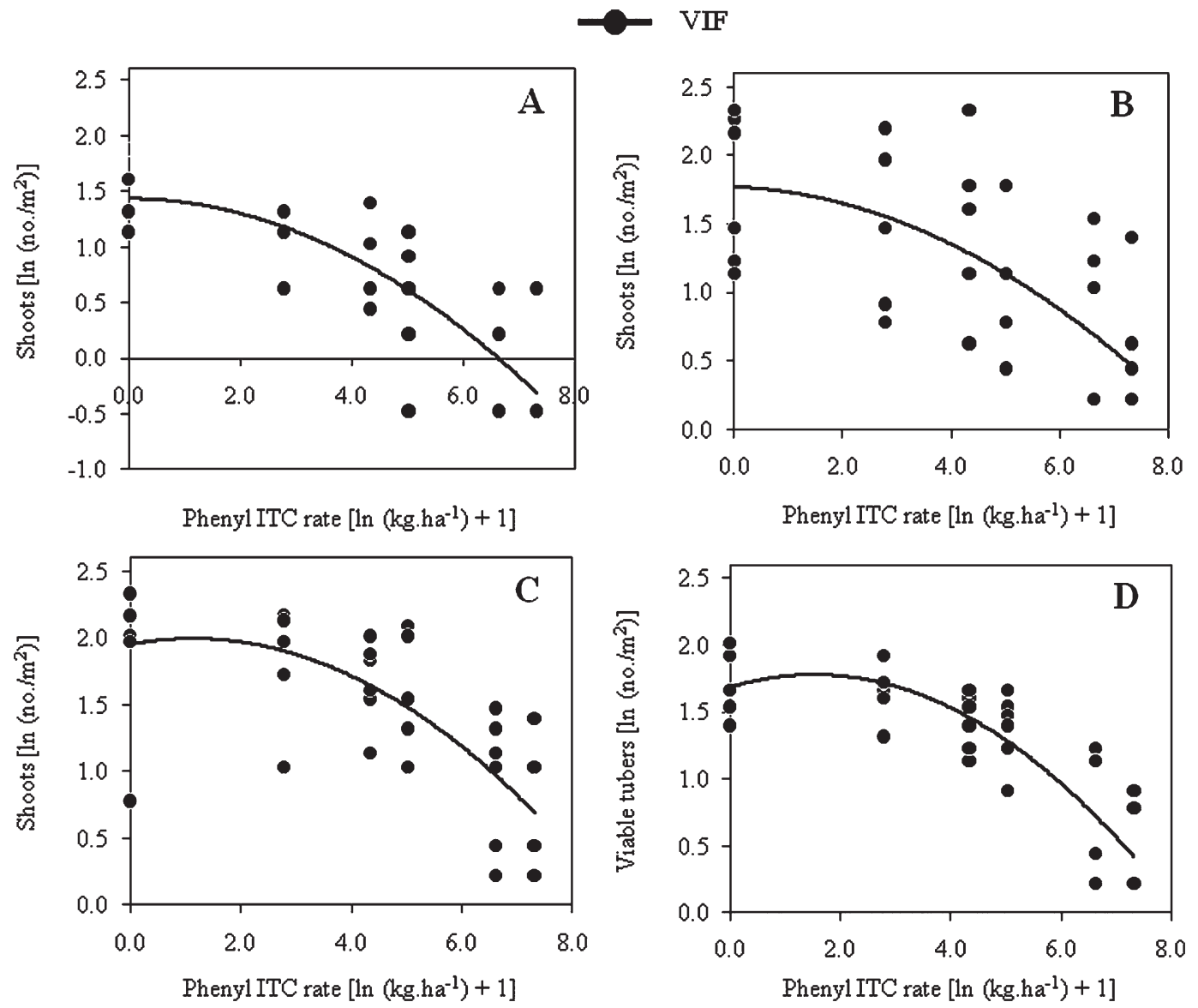

Fig. 3. Effect of phenyl isothiocyanate (ITC) rate under virtually impermeable film (VIF) mulch on purple nutsedge shoot and viable tuber densities, averaged over years (2006 and 2007). Closed circles are individual observations and solid lines are fitted regression equations. Regression equations for: (A) shoot density above mulch at 2 weeks, $\ln (y)=-0.0325\{\ln (x+1)\}^{2}-$ $0.0013\{\ln (\mathrm{x}+1)\}+1.4346 ;(\mathrm{B})$ shoot density above mulch at 4 weeks, $\ln (\mathrm{y})=-0.0222\{\ln (\mathrm{x}+1)\}^{2}-0.0159\{\ln (\mathrm{x}+1)\}+1.7710$; (C) shoot density below mulch at 4 weeks, $\ln (y)=-0.0340\{\ln (x+1)\}^{2}+0.0768\{\ln (x+1)\}+1.9512$; and (D) viable tuber density at 4 weeks, $\ln (y)=-0.0408\{\ln (x+1)\}^{2}+0.1245\{\ln (x+1)\}+1.6854$, where y is purple nutsedge shoot or viable tuber density $\left(\right.$ no. $\left./ \mathrm{m}^{2}\right)$ and $\mathrm{x}$ is phenyl ITC rate $\left(\mathrm{kg} \cdot \mathrm{ha}^{-1}\right) ; 1$ shoot or tuber $/ \mathrm{m}^{2}=0.0929$ shoot or tuber $/ \mathrm{ft}^{2}, 1 \mathrm{~kg} \cdot \mathrm{ha}^{-1}=0.8922 \mathrm{lb} / \mathrm{acre}$.

shoots $/ \mathrm{m}^{2}$ (83\% reduction) at phenyl ITC rates 750 and $1500 \mathrm{~kg} \cdot \mathrm{ha}^{-1}$, respectively. At 4 weeks after treatment, shoot density increased in all treatments, with 5.88 shoots $/ \mathrm{m}^{2}$ penetrated through the mulch in the nontreated control (Fig. 3B). Compared to the 108 purple nutsedge shoots $/ \mathrm{m}^{2}$ growing on bare-ground soil after 4 weeks, it is obvious that VIF mulch allowed only $1 / 18$ th of the purple nutsedge shoots to penetrate the mulch (data not shown). Therefore, VIF mulch provided a physical barrier that might have contributed to the suppression of purple nutsedge shoots. According to Santos et al. (2007), mulch thickness can affect nutsedge penetration through mulch.

Similar to 2 weeks after treatment, the highest two rates of phenyl ITC (750 and $1500 \mathrm{~kg} \cdot \mathrm{ha}^{-1}$ ) reduced purple nutsedge shoot density $\geq 66 \%$ ( $\leq 2.0$ shoots $/ \mathrm{m}^{2}$ ) at 4 weeks after treatments (Fig. 3B). These results are in agreement with previous greenhouse trials (Norsworthy and Meehan, 2005b) where yellow nutsedge emergence decreased with increased phenyl ITC rate, and the highest two concentrations of 676 and $1352 \mathrm{ppm}$ in dry soil (equivalent to field rate of 750 and $1500 \mathrm{~kg} \cdot \mathrm{ha}^{-1}$ ) reduced yellow nutsedge emergence $>74 \%$. Data on shoot density under polyethylene mulch at 4 weeks after treatment followed a similar response as followed by shoot density above mulch, and was described by a quadratic equation: $\ln (\mathrm{y})=$ $-0.0340\{\ln (\mathrm{x}+1)\}^{2}+0.0768\{\ln (\mathrm{x}+$ $1)\}+1.9512$ (Fig. 3C). Plots treated with phenyl ITC at $750 \mathrm{~kg} \cdot \mathrm{ha}^{-1}(2.64$ shoots $\left./ \mathrm{m}^{2}\right)$ and $1500 \mathrm{~kg} \cdot \mathrm{ha}^{-1}(2.0$ shoots $/ \mathrm{m}^{2}$ ) had $63 \%$ and $72 \%$ less shoot density under mulch than the nontreated control (Fig. 3C). Purple nutsedge viable tuber density was also decreased quadratically $[\ln (\mathrm{y})=$ $-0.0408\{\ln (\mathrm{x}+1)\}^{2}+0.1245\{\ln (\mathrm{x}+$ 1) $\}+1.6854$ ] in response to increased phenyl ITC rate (Fig. 3D). Purple nutsedge was predicted to produce 5.39 viable tubers $/ \mathrm{m}^{2}$ under VIF mulch in the absence of phenyl ITC (control treatment). Application of phenyl ITC at $750 \mathrm{~kg} \cdot \mathrm{ha}^{-1}$ under VIF mulch reduced viable tuber density to 2.06 tubers $/ \mathrm{m}^{2}$ (62\% reduction). Increasing the phenyl ITC rate to $1500 \mathrm{~kg} \cdot \mathrm{ha}^{-1}$ reduced tuber viability $72 \%\left(1.52\right.$ tubers $\left./ \mathrm{m}^{2}\right)$ compared with the nontreated control. In addition to reducing viability, ITC can induce secondary dormancy in seeds (Peterson et al., 2001). Norsworthy et al. (2006) also found that ITC delays purple nutsedge tuber sprouting over 3 weeks. Therefore, the dormancy induced by phenyl ITC can further delay 
the sprouting of viable tubers, which can provide a competitive advantage to vegetable crops. Low rates of phenyl ITC $\left(\leq 150 \mathrm{~kg} \cdot \mathrm{ha}^{-1}\right)$ failed to adequately suppress purple nutsedge shoot production above $(\leq 56 \%$ at 2 weeks and $\leq 47 \%$ at 4 weeks) and below polyethylene mulch $(\leq 38 \%)$ and to eliminate viable tubers $(\leq 33 \%)$ (Fig. 3, A-D).

Based on the fitted model, it was predicted that phenyl ITC rate of 4561 and $3360 \mathrm{~kg} \cdot \mathrm{ha}^{-1}$ will be needed to reduce the purple nutsedge shoot penetration through VIF mulch equivalent to $390 \mathrm{~kg} \cdot \mathrm{ha}^{-1}$ methyl bromide at 2 weeks $\left(0.41\right.$ shoots $/ \mathrm{m}^{2} ; 90 \%$ reduction) and 4 weeks (1.20 shoots/ $\mathrm{m}^{2} ; 80 \%$ reduction) after treatment, respectively. Likewise, shoot density of purple nutsedge under VIF mulch at 4 weeks will be comparable to methyl bromide ( 1.51 shoots $/ \mathrm{m}^{2} ; 79 \%$ reduction) if phenyl ITC is applied at 2839 $\mathrm{kg} \cdot \mathrm{ha}^{-1}$. Tuber viability data indicated that phenyl ITC at $289 \mathrm{l} \mathrm{kg} \cdot \mathrm{ha}^{-1}$ will be as effective as methyl bromide (1.09 tubers $/ \mathrm{m}^{2} ; 80 \%$ reduction) in reducing tuber viability. Therefore, to achieve purple nutsedge control equivalent to that provided by methyl bromide, phenyl ITC rates need to be increased nearly 1.9 to 3.0 times the highest applied rate $\left(1500 \mathrm{~kg} \cdot \mathrm{ha}^{-1}\right)$.

The results obtained under greenhouse and field conditions in controlling purple nutsedge were contradictory, with high efficacy of phenyl ITC in the greenhouse trial and low efficacy in the field trial. In the greenhouse trial, a low phenyl ITC concentration of $68 \mathrm{ppm}$ in dry soil (equivalent to a field rate of 75 $\mathrm{kg} \cdot \mathrm{ha}^{-1}$ ) was as effective as a higher concentration of $676 \mathrm{ppm}$ in dry soil (equivalent to a field rate of 750 $\mathrm{kg} \cdot \mathrm{ha}^{-1}$ ) for reducing purple nutsedge tuber viability. There may be four possible reasons for these contradictory results. First, in the greenhouse trial, phenyl ITC-treated soil containing tubers was placed in sealed glass jars, where losses were minimized by using a Teflon cap. However, in field trials, the soil was covered with VIF mulch. In the field, VIF mulch does not provide a completely sealed environment; hence, losses beneath the mulch would reduce the concentration and exposure duration of tubers to phenyl ITC. Obviously, the lower phenyl ITC concentration in the beds as a result of these losses was not adequate to control purple nutsedge. Second, the soil used for laboratory experiments was sterilized, which may have minimized any microbial degradation of phenyl ITC compared with field conditions. In a previous study, Price et al. (2005) recorded a 3-fold higher concentration of allyl ITC in autoclaved soil than in a nonautoclaved soil. Third, phenyl ITC was incorporated only in the top 3 -inches of soil in the field, and tubers below the 3 -inch layer did not receive effective doses of phenyl ITC, which may have reduced the control. However, generally, under field conditions, $>90 \%$ of purple nutsedge tubers are found up to 4.7 inches deep in the soil from the surface (Siriwardana and Nishimoto, 1987). The last possible reason could be associated with the dormancy of tubers. The rhizome chains of the purple nutsedge tubers used in the greenhouse trial were broken before being placed in jars. In contrast, under field conditions, most purple nutsedge tubers are connected in chains of rhizomes (Hauser, 1962). The removal of rhizomes from tubers break dormancy in purple nutsedge tubers, thereby making them more receptive to applied phenyl ITC under greenhouse conditions (Anderson, 1999; Holm et al., 1977). Although field plots were rototilled up to 3 inches deep before and after phenyl ITC application, some rhizome chains might have broken, but not all. However, to achieve effective control, the tubers of target weed species should be non-dormant and actively respiring during fumigation with ITC (AMVAC Chemical Corp., 2008). Therefore, any of these factors could explain why phenyl ITC may not be as effective against purple nutsedge tubers under field conditions as they were in the greenhouse experiment.

In summary, phenyl ITC proved effective against purple nutsedge at low concentrations when applied in a sealed environment. However, a sealed environment is not practical under field situations. A possible alternative to a sealed environment in the field can be the use of low-permeability polyethylene mulches. For instance, VIF mulch helps in maintaining higher concentration of phenyl ITC compared with LDPE mulch; therefore, improved weed control is expected. Although the highest phenyl ITC rate (1500 $\mathrm{kg} \cdot \mathrm{ha}^{-1}$ ) reduced the purple nutsedge shoot and tuber density $\geq 72 \%$, the level of control was not comparable to that provided by methyl bromide at 390 $\mathrm{kg} \cdot \mathrm{ha}^{-1}$. Based on the present research, it is concluded that phenyl ITC applied at the tested rates under a VIF mulch is not a potential effective alternative to methyl bromide for purple nutsedge control in densely infested fields.

\section{Literature cited}

AMVAC Chemical Corp. 2008. Vapam HL soil fumigant label. AMVAC Chemical Corp., Los Angeles.

Anderson, W.P. 1999. Perennial weeds: Characteristics and identification of selected herbaceous species. Iowa State Univ. Press, Ames, IA.

Austerweil, M., B. Steiner, and A. Gamliel. 2006. Permeation of soil fumigants through agricultural plastic films. Phytoparasitica 34:491-501.

Brown, P.D. and M.J. Morra. 1995. Glucosinolate-containing plant tissues as bioherbicides. J. Agr. Food Chem. 43:3070-3074.

Drobinca, L., P. Kristian, and J. Augustin. 1977. The chemistry of the NCS group, p. 1003-1197. In: S. Patai (ed.). The chemistry of cyanates and their derivatives. Wiley, New York.

Duniway, J.M. 2002. Status of chemical alternatives of methyl bromide for preplant fumigation in soil. Phytopathology 92:1337-1343.

Gardiner, J.B., M.J. Morra, C.V. Eberlein, P.D. Brown, and V. Borek. 1999. Allelochemicals released in soil following incorporation of rapeseed (Brassica napus) green manures. J. Agr. Food Chem. 47:3837-3842.

Hauser, E.W. 1962. Development of purple nutsedge under field conditions. Weeds 10:315-321.

Holm, L.G., D.L. Plucknett, J.V. Pancho, and J.P. Herberger. 1977. The world's worst weeds, distribution and biology. University Press of Hawaii, Honolulu, HI.

Morales-Payan, J.P., B.M. Santos, and T.A. Bewick. 1996. Purple nutsedge (Cyperus rotundus) interference on lettuce under different nitrogen levels. Proc. Southern Weed Sci. Soc. 49:201. (Abstr.).

Morales-Payan, J.P., B.M. Santos, and W.M. Stall. 1997a. Effect of increasing purple nutsedge (Cyperus rotundus) densities on cilantro (Coriandrum sativum) yield. Proc. Florida State Hort. Soc. 110:318-320.

Morales-Payan, J.P., B.M. Santos, W.M. Stall, and T.A. Bewick. 1997b. Effect of purple nutsedge (Cyperus rotundus) on tomato (Lycopersicon esculentum) and bell pepper (Capsicum annum) vegetative 
growth and fruit yield. Weed Technol. 11:672-676.

Morales-Payan, J.P., B.M. Santos, W.M. Stall, and T.A. Bewick. 1998. Interference of purple nutsedge (Cyperus rotundus) population densities on bell pepper ( Capsicum annum) yield as influenced by nitrogen. Weed Technol. 12:230-234.

Norsworthy, J.K. and J.V. Meehan, IV. 2005a. Herbicidal activity of eight isothiocyanates on Texas panicum (Panicum texacum), large crabgrass (Digitaria sanguinalis), and sicklepod (Senna obtusifolia). Weed Sci. 53:515-520.

Norsworthy, J.K. and J.V. Meehan, IV. 2005 b. Use of isothiocyanates for suppression of palmer amaranth (Amaranthus palmeri), pitted morningglory (Ipomoea lacunosa), and yellow nutsedge (Cyperus esculentus). Weed Sci. 53:884-890.

Norsworthy, J.K., M.S. Malik, P. Jha, and M.J. Oliveira. 2006. Effect of isothiocyanates on purple (Cyperus rotundus) and yellow nutsedge (Cyperus esculentus). Weed Biol. Manage. 6:131-138.

Patterson, D.T. 1998. Suppression of purple nutsedge (Cyperus rotundus) with polyethylene film mulch. Weed Technol. 12:275-280.

Peterson, J., R. Belz, F. Walker, and K. Hurle. 2001. Weed suppression by release of isothiocyanates from turnip-rape mulch. Agron. J. 93:37-43.

Price, A.J., C.S. Charron, A.M. Saxton, and C.E. Sams. 2005. Allyl isothiocyanate and carbon dioxide produced during degradation of Brassica juncea tissue in different soil conditions. HortScience 40:1734-1739.

Santos, B.M., J.P. Gilreath, and M.N. Siham. 2007. Comparing fumigant retention of polyethylene mulches for nutsedge control in Florida spodosols. HortTechnology 17:308-311.

Santos, B.M., J.P. Morales-Payan, W.M. Stall, and T.A. Bewick. 1998. Influence of purple nutsedge (Cyperus rotundus) density and nitrogen on radish (Raphanus sativus) yield. Weed Sci. 46:661-664.

Siriwardana, G. and R.K. Nishimoto. 1987. Propagules of purple nutsedge (Cyperus rotundus) in soil. Weed Technol. 1:217-220.
Stoller, E.W. and R.D. Sweet. 1987. Biology and life cycle of purple and yellow nutsedge (Cyperus rotundus and C. esculentus). Weed Technol. 1:66-73.

Stuart, A. and J.K. Ord. 1994. Kendall's advance theory of statistics. Edward Arnold, London.

Teasdale, J.R. and R.B. Taylorson. 1986. Weed seed response to methyl isothiocyanate and metham. Weed Sci. 34:520-524.

U.S. Environmental Protection Agency. 2008. Ozone layer depletion: Regulatory programs: The phase-out of methyl bromide Montreal protocol. 15 Sept. 2008. <http://www.epa.gov/ozone/mbr/index. html>.

Webster, T.M. 2002. Weed survey: Southern states: Vegetable, fruit and nut crops subsection. Proc. Southern Weed Sci. Soc. 55:237-258. (Abstr.).

William, R.D. and G.F. Warren. 1975. Competition between purple nutsedge and vegetables. Weed Sci. 23:317-323.

Yates, S.R., J. Gan, S.K. Papiernik, R. Dungan, and D. Wang. 2002. Reducing the fumigant emission after soil application. Phytopathology 92:1344-1348. 